\title{
To study the relationship between religious coping spiritual well being, and marital adjustment, among the wives of males with Alcohol Dependence Syndrome.
}

\author{
Chettri GT ${ }^{1}$, Pathak $\mathbf{N}^{2}$
}

1.Clinical Psychologist, Mental Hospital Lagankhel,Nepal 2. Consultant psychiatrist, Armed police force Hospital, Kathmandu

E-mail *Corresponding author : trishnaghosh@gmail.com

\begin{abstract}
Introduction: The impact of alcoholism on marital - family functioning and the influence of marital - family relationship on the development and the maintenance of the alcoholism are challenging problems to both the clinicians and researchers. The aim was to study the relationship between religious coping spiritual well being, and marital adjustment, among the wives of males with Alcohol Dependence Syndrome.

Material And Method: Wives of alcohol dependent male patients admitted in the Department of Psychiatry, Armed Police force Hospital were included in the study after informed consent. a) Semi-Structured Proforma $b$ ) The Spiritual Well-Being Scale, C) R-COPE Scale, (D) Dyadic Adjustment Scale. were used to collect the data.

Results: The results of the study show that majorities were from a rural background, low socio economic status, nuclear family and were homemakers. Spiritual well being and religious well being correlated positively with positive religious coping and inversely correlated with negative religious coping. The total score on religious coping correlated inversely with the dyadic adjustment showing that in times of stress and low marital adjustment the sample turned more to religion to help them cope. High negative correlation was seen between the dyadic adjustment of the wives and negative religious coping. The years of drinking inversely correlated with spiritual well being and the subscale of existential well being, indicating that the more number of years the patient consumed alcohol the wife had lower spiritual well being and in particular existential well being.
\end{abstract}

Conclusion: Spiritual well being enhances the positive religious coping strategies of the wives of men with alcoholism in this study. When the spiritual well being is low more negative methods of religious coping are used.

Keywords: Religious coping, Spiritual well being, Marital adjustment

\section{INTRODUCTION}

Marital and family problems may precede the alcoholism, may occur solely as a result of the alcohol consumption and the consequent behaviour changes, or may be part of a complex interaction between pre-existing weaknesses of the family or of the individuals in the family and the drinking of the family member. Alcohol families are characterized by a general atmosphere of moodiness, tension, and irritability, communication problems with the spouse $^{1}$, incongruent perceptions between alcoholics and their wives², low cohesion, expressiveness and recreational orientation 3 family violence ${ }^{4}$, and increased psychological distress in the children 5 .

Appropriate or inappropriate coping strategies adopted by the wives to deal with the stress depend partly on the social adjustment of individual with drug or alcohol dependence and 
severity of addiction. The coping strategies used by them include pleading, threatening, arguing, avoiding, withdrawing sexually, being indulgent, taking greater control on responsibilities seeking outside help and taking steps towards separation. ${ }^{6}$

Religion is a form of coping that helps individuals to deal with a wide variety of difficult life situations, particularly with long term stressors.

\section{MATERIAL AND METHOD}

Forty alcohol dependent male patients, who are admitted in the Department of Psychiatry, Armed Police force Hospital ,married for at least two years and above and living with the patient, fluent in either of the following languages English, and who gave a written informed consent. a.

Spouses of patients who have co-morbid Axis I psychiatric diagnosis, Not living in the same house due to separation or divorce and who themselves are alcohol dependent were excluded. Data was collected from the wives, whose partners were admitted to both the centers for a period of 4 months, after informed consent all the individuals were rated on a) Semi-Structured Proforma b) The Spiritual Well-Being Scale ${ }^{7}$, C) R- COPE Scale ${ }^{8}$, (D) Dyadic Adjustment Scale. ${ }^{9}$

\section{RESULT}

Shows the distribution of the wives with respect to their sociodemographic variables. Majority of the spouses i.e., 21 (52.5\%) were in the age group of $31-40$ years. Fourteen $(35.0 \%)$ had studied upto the middle level. Majority(57.5\%) were Homemakers. Detail of the Socio-demographic detail is presented in Table1.

Table 2 presents the distribution of the wives with regard to the number of years of marriage. Distribution of the patients across the number of years of drinking is described in table 3 .

The religious well being subscale had a mean of 39.90 (SD 8.09) and a range of 20-53. The existential well being subscale had a mean of 37.12 (SD 6.76) and a range of 20-53. (Table 4)

The RCOPE total had a mean of 102.27 (SD 23.57) with a range of 38.164. (Table 5)
Table 1: Socio-demographic Characteristics Of the Subjects

\begin{tabular}{|c|c|c|}
\hline Variables & Frequency & Percentage \\
\hline $\begin{array}{l}\text { Age } \\
21-30 \\
31-40 \\
41-50\end{array}$ & $\begin{array}{l}9 \\
21 \\
10\end{array}$ & $\begin{array}{l}22.5 \% \\
52.5 \% \\
25 \%\end{array}$ \\
\hline $\begin{array}{l}\text { Educational Status } \\
\text { Illiterate } \\
\text { Primary } \\
\text { Middle } \\
\text { High school } \\
\text { PUC } \\
\text { Degree / Diploma }\end{array}$ & $\begin{array}{l}3 \\
5 \\
14 \\
11 \\
4 \\
3\end{array}$ & $\begin{array}{l}7.5 \% \\
12.5 \% \\
35.0 \% \\
27.5 \% \\
10.0 \% \\
7.5 \% \\
\end{array}$ \\
\hline $\begin{array}{l}\text { Occupation Status } \\
\text { Daily wage earner } \\
\text { Clerical } \\
\text { Homemaker }\end{array}$ & $\begin{array}{l}14 \\
3 \\
23\end{array}$ & $\begin{array}{l}35.0 \% \\
7.5 \% \\
57.5 \%\end{array}$ \\
\hline $\begin{array}{l}\text { Religion } \\
\text { Hindu } \\
\text { Christian } \\
\text { Muslim } \\
\text { Others }\end{array}$ & $\begin{array}{l}32 \\
6 \\
1 \\
1\end{array}$ & $\begin{array}{l}80 \% \\
15 \% \\
2.5 \% \\
2.5 \%\end{array}$ \\
\hline $\begin{array}{l}\text { Background } \\
\text { Rural } \\
\text { Semi-urban } \\
\text { Urban }\end{array}$ & $\begin{array}{l}35 \\
3 \\
2 \\
\end{array}$ & $\begin{array}{l}87.5 \% \\
7.5 \% \\
5 \%\end{array}$ \\
\hline $\begin{array}{l}\text { Income (per month ) } \\
<1000 \\
1001-2000 \\
2001-3000 \\
3001-4000 \\
>4000\end{array}$ & $\begin{array}{l}10 \\
15 \\
1 \\
8 \\
6 \\
\end{array}$ & $\begin{array}{l}25 \% \\
37.5 \% \\
2.5 \% \\
20 \% \\
15 \% \\
\end{array}$ \\
\hline $\begin{array}{l}\text { Family Type } \\
\text { Nuclear } \\
\text { Joint } \\
\text { Extended }\end{array}$ & $\begin{array}{l}27 \\
8 \\
5\end{array}$ & $\begin{array}{l}67.5 \% \\
20 \% \\
12.5 \%\end{array}$ \\
\hline $\begin{array}{l}\text { Number of children } \\
\text { None } \\
\text { One } \\
\text { Two } \\
\text { Three } \\
\text { Four }\end{array}$ & $\begin{array}{l}2 \\
7 \\
17 \\
13 \\
1\end{array}$ & $\begin{array}{l}5 \% \\
17.5 \% \\
42.5 \% \\
32.5 \% \\
2.5 \%\end{array}$ \\
\hline $\begin{array}{l}\text { Head of the family } \\
\text { Patient } \\
\text { Spouse } \\
\text { Others }\end{array}$ & $\begin{array}{l}31 \\
1 \\
8 \\
\end{array}$ & $\begin{array}{l}77.5 \% \\
2.5 \% \\
20 \%\end{array}$ \\
\hline $\begin{array}{l}\text { Main bread winner } \\
\text { Patient } \\
\text { Spouse } \\
\text { Others } \\
\end{array}$ & $\begin{array}{l}33 \\
2 \\
5\end{array}$ & $\begin{array}{l}82.5 \% \\
5 \% \\
12.5 \% \\
\end{array}$ \\
\hline
\end{tabular}


Table 2: Distribution According to the Years of

\begin{tabular}{|l|l|l|}
\hline \multicolumn{3}{|c|}{ Marriage } \\
\hline Variable & Frequency & Percentage \\
\hline$<5$ years & 4 & $10 \%$ \\
$5-10$ & 9 & $22.5 \%$ \\
$10-15$ & 8 & $20 \%$ \\
$15-20$ & 8 & $20 \%$ \\
$20-25$ & 11 & $27.5 \%$ \\
\hline
\end{tabular}

Table 3: Distribution of Patients According to the Years of Drinking

\begin{tabular}{|l|l|l|}
\hline Variable & Frequency & Percentage \\
\hline$<5$ years & 2 & $5 \%$ \\
$5-10$ & 8 & $20 \%$ \\
$10-15$ & 3 & $7.5 \%$ \\
$15-20$ & 19 & $47.5 \%$ \\
$20-25$ & 4 & $10 \%$ \\
$25-30$ & 4 & $10 \%$ \\
\hline
\end{tabular}

Table 4: Distribution of SWB, and the subscales RWBS and SWBS

\begin{tabular}{|l|l|l|l|l|}
\hline & Minimum & Maximum & Mean & $\begin{array}{l}\text { Std. } \\
\text { Deviation }\end{array}$ \\
\hline $\begin{array}{l}\text { SWB - } \\
\text { Total }\end{array}$ & 52 & 104 & 76.72 & 12.76 \\
\hline RWBS & 20 & 53 & 39.90 & 8.09 \\
\hline EWBS & 20 & 53 & 37.12 & 6.76 \\
\hline
\end{tabular}

SWB $=$ Total- Spiritual Well Being (scores range from - 20 to 120), RWBS = Religious Well Being (scores range from 10 to 60 ), EWBS = Existential Well Being (scores range from - 10 to 60 )

Table 5: Distribution of RCOPE Total Score, RCOPE Positive And RCOPE Negative Scores

\begin{tabular}{|l|l|l|l|l|}
\hline & Minimum & Maximum & Mean & $\begin{array}{l}\text { Std. } \\
\text { Deviation }\end{array}$ \\
\hline $\begin{array}{l}\text { RCOPE } \\
\text { Total }\end{array}$ & 38 & 164 & 102.27 & 23.57 \\
\hline $\begin{array}{l}\text { RCOPE } \\
\text { Positive }\end{array}$ & 21 & 105 & 72.62 & 17.00 \\
\hline $\begin{array}{l}\text { RCOPE } \\
\text { Negative }\end{array}$ & 11 & 59 & 29.65 & 12.94 \\
\hline
\end{tabular}

The Dydadic Adjustment (DAS) - total score had a mean of 94.67 (SD 18.96) with a range of 49-130. The dyadic satisfaction subscale had a mean of 43.92 (SD 11.53) and a range of 14-65. Detail of the score is described in Table 6 .
Table 5: Distribution of DAS Total Scores and Subscale scores of subjects.

\begin{tabular}{|l|l|l|l|l|}
\hline & Minimum & Maximum & Mean & Std. Deviation \\
\hline $\begin{array}{l}\text { DAS total } \\
\text { score }\end{array}$ & 49 & 130 & 94.67 & 18.96 \\
\hline $\begin{array}{l}\text { Dyadic } \\
\text { satisfaction }\end{array}$ & 14 & 65 & 43.92 & 11.53 \\
\hline $\begin{array}{l}\text { Dyadic } \\
\text { cohesion }\end{array}$ & 15 & 44 & 29.95 & 6.55 \\
\hline $\begin{array}{l}\text { Dyadic } \\
\text { consensus }\end{array}$ & 1 & 23 & 13.72 & 5.11 \\
\hline $\begin{array}{l}\text { Affectional } \\
\text { expression }\end{array}$ & 0 & 12 & 7.07 & 2.87 \\
\hline
\end{tabular}

Table 7: Pearson's Correlation Coeffecient Matrix Of the Spiritual Well Being and It's Subscales, Religious Coping and It's Domains and Dydadic Adjustment

\begin{tabular}{|l|l|l|l|l|l|l|l|}
\hline & $\begin{array}{l}\text { SWB } \\
\text { total }\end{array}$ & RWBS & EWBS & $\begin{array}{l}\text { RCOPE } \\
\text { total }\end{array}$ & $\begin{array}{l}\text { RCOPE } \\
\text { positive }\end{array}$ & $\begin{array}{l}\text { RCOPE } \\
\text { negative }\end{array}$ & $\begin{array}{l}\text { DAS } \\
\text { total }\end{array}$ \\
\hline SWB & & $.843\left(^{(*)}\right)$ & $.835\left(^{* *}\right)$ & .065 & $.374\left(^{*}\right)$ & $-.373\left(^{*}\right)$ & .264 \\
\hline RWBS & & & $.521\left(^{* *}\right)$ & .016 & $.31\left(^{*}\right)$ & $-.382\left(^{*}\right)$ & .261 \\
\hline EWBS & & & & .067 & .272 & -.236 & .212 \\
\hline $\begin{array}{l}\text { RCOPE- } \\
\text { Total }\end{array}$ & & & & & $.84\left(^{(* *}\right)$ & $.71\left(^{(* *)}\right.$ & $-.314\left(^{*}\right)$ \\
\hline $\begin{array}{l}\text { RCOPE- } \\
\text { Positive }\end{array}$ & & & & & & .225 & -.024 \\
\hline $\begin{array}{l}\text { RCOPE } \\
- \\
\text { Negative }\end{array}$ & & & & & & & $-.540\left(^{* *}\right)$ \\
\hline $\begin{array}{l}\text { DAS } \\
\text { Total }\end{array}$ & & & & & & & \\
\hline
\end{tabular}

SWB $=$ Spiritual well being, RWBS $=$ Religious well being, EWBS = Existential well being, RCOPE Total $=$ Religious cope total score, RCOPE Positive $=$ Positive religious cope, RCOPE Negative = Negative religious cope, DAS Total $=$ Dyadic adjustment score, Values of parenthesis are Pearson's correlation coefficient (r) 2 tailed significance, ${ }^{* *} \mathrm{p}<$ $0.01,{ }^{*} \mathrm{p}<0.05$ 
TABLE 8: Pearson's Correlation Coefficient Of SWB, RWBS, EWBS, RCOPE, RCOPE Positive, RCOPE Negative and Das total

\begin{tabular}{|l|l|l|l|l|l|l|l|}
\hline & SWB & RWBS & EWBS & RCOPE & $\begin{array}{l}\text { RCOPE } \\
\text { Positive }\end{array}$ & $\begin{array}{l}\text { RCOPE } \\
\text { Negative }\end{array}$ & $\begin{array}{l}\text { DAS } \\
\text { Total }\end{array}$ \\
\hline $\begin{array}{l}\text { Years of } \\
\text { marriage }\end{array}$ & -.232 & -.246 & -.240 & -.072 & -.090 & -.013 & -.115 \\
\hline $\begin{array}{l}\text { Years of } \\
\text { drinking }\end{array}$ & $-.357\left(^{*}\right)$ & -.222 & $-.394\left(^{*}\right)$ & -.060 & -.313 & .302 & -.266 \\
\hline
\end{tabular}

$S W B=$ Spiritual well being,$R W B S=$ Religious well being, EWBS = Existential well being, DAS Total

$=$ Dyadic adjustment score total

Table 9: Mean Scores On SWB, RCOPE and DAS Of The Different Age Groups

\begin{tabular}{|l|l|l|l|l|l|}
\hline \multirow{2}{*}{ Variables } & \multicolumn{3}{|l|}{ Mean scores of the age groups } & ANOVA & \multirow{2}{*}{ F-statistic } \\
\cline { 2 - 6 } & $\mathbf{1}$ & $\mathbf{2}$ & $\mathbf{3}$ & .539 & .588 \\
\hline SWB & 80.56 & 76.00 & 74.80 & .498 & .611 \\
\hline RCOPE & 95.33 & 104.67 & 103.50 & .454 & .247 \\
\hline DAS & 102.67 & 94.42 & 88.00 & 1.454 \\
\hline
\end{tabular}

$1=21-30$ years age, $2=31-40$ years age, $3=41-50$ years age, $S W B=$ Spiritual well being total score,

RCOPE $=$ Religious coping total score, DAS = Dyadic adjustment scale total score, ${ }^{*}=$ Significant

Table 10: Mean Scores on SWB, RCOPE and DAS of Education

\begin{tabular}{|l|l|l|l|l|l|l|l|l|}
\hline \multirow{2}{*}{ Variable } & \multicolumn{9}{|l|}{ Mean scores - Education } & $\begin{array}{l}\text { ANOVA F- } \\
\text { statistic }\end{array}$ & $\mathbf{p}$ \\
\cline { 2 - 8 } & $\mathbf{1}$ & $\mathbf{2}$ & $\mathbf{3}$ & $\mathbf{4}$ & $\mathbf{5}$ & $\mathbf{6}$ & .513 \\
\hline SWB & 82.0 & 86.60 & 74.78 & 74.27 & 76.25 & 73.67 & .867 & $0.044^{*}$ \\
\hline RCOPE & 130.33 & 97.40 & 109.57 & 99.91 & 85.00 & 80.00 & 2.584 & .073 \\
\hline DAS & 75.00 & 110.80 & 95.71 & 93.73 & 100.75 & 78.00 & 2.234 & \\
\hline
\end{tabular}

1 = Illiterat, $2=$ Primary, $3=$ Middle , $4=$ High school, $5=$ Pre-University, $6=$ Diploma $/$ Degree,

$S W B=$ Spiritual well being total score,$R C O P E=$ Religious coping total score, $D A S=$ Dyadic adjustment scale total score $*$ Significant

\section{Table 11: Mean Scores on SWB, RCOPE and DAS Of Occupation}

\begin{tabular}{|l|l|l|l|l|l|}
\hline \multirow{2}{*}{ Variables } & Mean scores - Occupation & ANOVA & \multirow{2}{*}{$\mathbf{p}$} \\
\cline { 2 - 5 } & $\mathbf{1}$ & $\mathbf{2}$ & $\mathbf{3}$ & F-statistic & \\
\hline SWB & 79.36 & 67.00 & 76.39 & 1.187 & 0317 \\
\hline RCOPE & 111.86 & 104.67 & 96.13 & 2.059 & .142 \\
\hline DAS & 93.79 & 87.67 & 96.13 & .277 & .759 \\
\hline
\end{tabular}

$1=$ Daily wage earner, $2=$ Clerical, $3=$ Homemaker,

$S W B=$ Spiritual well being total score,$R C O P E=$ Religious coping total score, $D A S=$ Dyadic adjustment scale total score

* = Significant

Table 12: Mean Scores on SWB, RCOPE and DAS of Income

\begin{tabular}{|c|c|c|c|c|c|}
\hline \multirow{2}{*}{ Variables } & \multicolumn{3}{|c|}{ Mean scores - Income } & \multirow{2}{*}{$\begin{array}{l}\text { ANOVA } \\
\text { F-statistic }\end{array}$} & \multirow{2}{*}{$\mathbf{p}$} \\
\hline & 1 & 2 & 3 & & \\
\hline SWB & 79.10 & 75.87 & 76.00 & .222 & .802 \\
\hline RCOPE & 114.80 & 100.00 & 96.20 & 2.089 & .138 \\
\hline DAS & 95.60 & 95.00 & 93.73 & .031 & .970 \\
\hline
\end{tabular}

$1=<1000,2=1001-2000,3=>2000$

$S W B=$ Spiritual well being total score, $R C O P E=$ Religious coping total score, $D A S=$ Dyadic adjustment scale total score

* $=$ Significant 
Correlations between the spiritual well being (SWB) score, the religious well being subscales (SWBS), the existential well being subscales (EWBS), the RCOPE total score, the scores on the RCOPE positive domain and RCOPE negative domain and the Dyadic Adjustment Scale (DAS) total scores is shown in Table 7.

Detail of the correlation between the number of years of marriage and the number of years of drinking with spiritual well being (SWB), religious coping positive (RCOPE positive) and negative (RCOPE negative) and dyadic adjustment (DAS) is illustrated in Table 8.

Table 9. shows the mean scores on spiritual well being (SWB), RCOPE and dyadic adjustment (DAS) over the different age groups

The mean scores on spiritual well being (SWB), RCOPE and dyadic adjustment (DAS) over the levels of education of the wives is shown in Table 10.

The mean scores on spiritual well being (SWB), RCOPE and dyadic adjustment (DAS) over the different occupations is tabulated in Table 11.

Table 12. shows the mean scores on spiritual well being (SWB), RCOPE and dyadic adjustment (DAS) over the income levels.

\section{DISCUSSION:}

Spiritual well being enhances the positive religious coping strategies of the wives of men with alcoholism in this study. When the spiritual well being is low more negative methods of religious coping are used. Low marital adjustment of the wives lead to an increased need to use religious methods of coping and more often negative religious coping is used. More years of alcohol consumption of the patient lead to low spiritual and existential well being in the wife. Wives who had lower education had used religious coping more than those who were higher educated.

\section{ACKNOWLEDGEMENT: None}

\section{CONFLICT OF INTEREST: None}

\section{REFERENCES:}

1.Vannicelli, M., Gingerich, $S \mathcal{E}$ Ryback, R. Family problems related to the treatment and outcome of alcoholic patients. British J. Addiction.1983;78, 193-204.
2.Spiegel D, Wissler T. Perceptions of family environment among psychiatric patients and their wives. Family process. 1983; 22, 535-547.

3.Moos RH,Moos BS. The process of recovery from alcoholism III: comparing functioning in families, of alcoholics and matched control families, J.studies on Alcohol.1984; 45, 111-118.

4.Plutchik A,Plutchik, $R$.Psychosocial correlates of alcoholism. Integrated Psychiatry.1989; 6:205-210.

5.Drake RE,Vaillant GE. Predicting alcoholism and personality disorder in a 33 year longitudinal study of children of alcoholics. British J.Addiction, 1988; 83:799807.

6.Oxford J. (1975) Alcoholism and marriage: The argument against specialism, In Bhowmick, P., Tripathi HP, Pandey RM. Indian J.Psychiatry, 2001, 43:219-224.

7.Paloutzian RF, Ellison CW. Loneliness, spiritual well being and the quality of life. In L.A. Peplau and D. Perlman (Eds.) Loneliness: A sourcebook of current theory, research and therapy, N.Y.: Wiley, pp. 1982; 224237.

8.Pargament KI, Koenig HG, Perez LM. The many methods of religious coping: Development and initial validation of the RCOPE. J. Clinical Psychology. 2000; 56, 519-543.

9.Spanier GP. Measuring Dyadic Adjustment: New scales for assessing the quality of marriage and similar dyads. J.Marriage and the family.1976; 15, 15-28.

10.Siegal B. Love, medicine and miracles. New York: Harper \& Row. 1992.

11.Levin JS, Markides KS. Religious attendance and subjective health.J.scientific study of Religion, 1986;25:31-40.

12.Pargament KI, Brant CR. Religion and Coping. In H.G. Koenig (Ed.), Handbook of religion and mental health. New York: Academic Press. 1998.

13.Pargament KI, Koenig HG, Tarakeshwar N, Hahn J. Religious Coping Methods as Predictors of Psychological, Physical and Spiritual Outcomes among Medically Ill Elderly Patients: A Two-year Longitudinal Study. J.Health Psychology.2004; 9; 6, 713-730.

14.Pargament KI, Smith B, Koenig HG, Perez LM. Patterns of positive and negative religious coping with major life stressors. J.Scientific Study of Religion 1998; 37:710-724

15. Ellison CG, Boardman JD, Williams DR, Jackson JS. Religious involvement, stress and mental health: Findings from the 1995 Detroit Area study. Social Forces. 2001; 8, 215-249.

16.Orathinkal J, Vansteenwegen A.Religiosity and Marital Satisfaction Contemporary Family Therapy.2006; 28; 4, 497-504(8).

17.Bjorck JP, Thurman, JW. Negative Life Events, Patterns of Positive and Negative Religious Coping, and Psychological Functioning.J.Scientific Study of Religion, 2007;46; 2, 159:167-9.

18.Bearon LB, Koenig HG. Religious cognition and use of prayer in health and illness. Gerontologist. 1990; 30:249253. 